Jurnal MAKSIPRENEUR, Vol. VI, No. 1, Des 2016, hal. 14 - 23

\title{
PENGARUH KECERDASAN EMOSIONAL, TINGKAT IDEALISME, PERILAKU BELAJAR DAN LOCUS OF CONTROL TERHADAP TINGKAT PEMAHAMAN AKUNTANSI MAHASISWA STRATA SATU (S-1) AKUNTANSI PADA PERGURUAN TINGGI DI KABUPATEN BANYUMAS
}

Dona Primasari (Dona_primasari@yahoo.com)

Fakultas Ekonomi dan Bisnis Universitas Jenderal Soedirman

ABSTRACT. This study aims to examine the influence of emotional intelligence, the level of idealism, learning behavior and the locus of control of students to the understanding of accounting. The sample consists of accounting students in Banyumas District. Data analysis using SPSS. The results showed that the emotional intelligence, the level of idealism, and the locus of control students influence the understanding of accounting, while the behavior of learning proved not to affect the understanding of accounting.

Keywords: emotional intelligence, level of idealism, learning behavior, locus of control, understanding of accounting

\section{PENDAHULUAN}

Di dalam pasal 1 butir 20 UU No. 20 Tahun 2003 tentang sistem pendidikan nasional, dinyatakan bahwa "pembelajaran adalah proses interaksi peserta didik dengan pendidik dan sumber belajar pada suatu lingkungan belajar". Di lingkungan pendidikan tinggi, interaksi tersebut terjadi antara mahasiswa dengan dosen. Dalam interaksi yang berpusat pada mahasiswa tersebut terjadi proses perubahan yang dialami mahasiswa dalam empat ranah yaitu, ranah pengetahuan (kognitif), ranah perasaan (afektif), ranah keterampilan (psikomotorik), dan ranah kerjasama. Word Conference On Higher Education yang di selenggarakan oleh UNESCO di Paris tahun 1998, menyebutkan keempat ranah tersebut dengan istilah learning to know, learning to be, learning to do, dan learning to live together. Belajar merupakan salah satu faktor yang mempengaruhi dan berperan penting dalam pembentukan pribadi dan perilaku individu. Sukmadinata (2005) menyebutkan bahwa sebagian terbesar perkembangan individu berlangsung melalui kegiatan belajar.

Proses belajar di perguruan tinggi adalah proses yang sifatnya kompleks dan menyeluruh. Banyak orang yang berpendapat bahwa untuk meraih prestasi atau tingkat pemahaman yang tinggi dalam belajar, seseorang harus memiliki Intelligence Quotient (IQ) yang tinggi, karena inteligensi merupakan bekal potensial yang akan memudahkan dalam belajar dan pada gilirannya akan menghasilkan tingkat pemahaman yang optimal. Kenyataannya, dalam proses belajar mengajar sering ditemukan mahasiswa yang tidak dapat meraih prestasi belajar yang setara dengan kemampuan inteligensinya. Ada mahasiswa yang mempunyai kemampuan inteligensi tinggi tetapi memperoleh prestasi belajar yang relatif rendah, namun ada mahasiswa yang walaupun kemampuan inteligensinya relatif rendah, 
dapat meraih prestasi belajar yang relatif tinggi. Itu sebabnya taraf inteligensi bukan merupakan satu-satunya faktor yang menentukan keberhasilan seseorang, karena ada faktor lain yang mempengaruhi (Sugiartini 2008).

Menurut Goleman (2004) dalam Primasari dkk (2011), kecerdasan intelektual (IQ) hanya menyumbang $20 \%$ bagi kesuksesan, sedangkan $80 \%$ adalah sumbangan faktor kekuatan-kekuatan lain, diantaranya adalah kecerdasan emosional atau Emotional Intellegence. Penelitian yang dilakukan Marwanto (2008) menemukan bahwa tingkat idelisme dan umur berpengaruh signifikan terhadap senstivitas moral mahasiswa. Hal ini disebabkan karena mahasiswa yang memiliki kemampuan berpikir secara moral dan mempunyai tingkat idealis yang tinggi akan lebih mampu untuk mengetahui hadirnya masalah-masalah etika serta memutuskan suatu tindakan lebih mengarah pada pedoman atau aturan yang telah ditetapkan sebelumnya.

Menurut Brownell (1982) Locus of control merupakan salah satu faktor individual yang mempengaruhi cara pandang seseorang terhadap suatu peristiwa, bisa tidaknya ia mengendalikan peristiwa tersebut, serta dorongan untuk menjadi seseorang/sesuatu sesuai dengan ambisinya (Robbins, 2006). Locus of control telah dianggap suatu dari ciri watak kepribadian yang lebih teguh atau stabil yang ada pada diri seorang individu (Koford dan Pennu, 1992). Dalam literatur moral menyatakan bahwa locus of control sebagai suatu ciri watak kepribadian memberikan pengaruh pada pembuatan keputusan dan tingkah laku (Chiu, 2003 dalam Chan dan Leung, 2006). Riset yang dilakukan oleh Chan dan Leung (2006), menemukan bahwa Locus of control sebagai pembentuk perilaku moral mahasiswa. Penelitian kali ini mencoba menelaah kembali riset-riset yang telah dilakukan oleh Chan dan Leung (2006), Primasari (2011) dan Marwanto (2008) yang menyebutkan ada faktor lain diluar dari kecerdasan emosional yang berpengaruh dalam kehidupan individual, salah satunya adalah perilaku belajar mahasiswa. Penelitiann ini menguji anteseden tingkat pemahaman akuntansi mahasiswa di Kabupaten Banyumas, adapun variabel anteseden terdiri atas pengaruh kecerdasan emosional, tingkat idealisme, perilaku belajar dan locus of control.

Berdasarkan latar belakang di atas dan riset-riset terdahulu, maka dikemukakan hipotesis sebagai berikut:

H1: Kecerdasan emosional berpengaruh terhadap pemahaman akuntansi mahasiswa

H2: Tingkat idealisme berpengaruh terhadap pemahaman akuntansi mahasiswa

H3: Perilaku belajar berpengaruh terhadap pemahaman akuntansi mahasiswa

H4: Locus of control berpengaruh terhadap pemahaman akuntansi mahasiswa

\section{METODOLOGI PENELITIAN}

1. Jenis Penelitian

Jenis penelitian yang digunakan dalam penelitian ini adalah penelitian asosiatif. Penelitian asosiatif adalah penelitian yang minimal terdapat dua variabel yang dihubungkan. Jadi penelitian asosiatif merupakan suatu penelitian yang mencari hubungan antara satu variabel dengan variabel yang lain. Hubungan antara variabel ada tiga bentuk, yaitu: simetris, kausal, dan interaktif (Sugiyono, 2004). Hubungan yang digunakan dalam penelitian ini adalah hubungan kausal.

\section{Populasi dan Sampel}

Populasi dalam penelitian ini adalah semua mahasiswa strata satu (S-1) jurusan akuntansi yang aktif dan terdaftar di Fakultas Ekonomi Bisnis pada Universitas Jenderal Soedirman, Universitas Muhammadiyah Purwokerto, dan STIE Satria Purwokerto. 
Metode pengambilan sampel yang dilakukan dalam penelitian ini adalah metode probability sampling. Metode ini berupa purposive sampling. Purposive sampling yaitu teknik penentuan sampel dengan pertimbangan tertentu. Sampel penelitian ini diambil dari mahasiswa angkatan 2013, 2014, 2015. Adapun kriteria pemilihan sampel dalam penelitian ini adalah: 1). Mahasiswa Strata satu (S-1) jurusan akuntansi yang aktif dan terdaftar pada Fakultas Ekonomi Bisnis pada Universitas Jenderal Soedirman, Universitas Muhammadiyah Purwokerto, STIE Satria Purwokerto. 2). Mahasiswa Strata satu (S-1) yang telah menempuh mata kuliah pengantar akuntansi 1, pengantar akuntansi 2, akuntansi keuangan menengah 1, akuntansi keuangan menengah 2, akuntansi keuangan lanjutan 1, akuntansi keuangan lanjutan 2 , audit 1 , audit 2 , audit 3 , dan teori akuntansi.

Sumber Data yang digunakan dalam penelitian ini adalah: a) Data primer. Data primer adalah data penelitian yang diperoleh secara langsung dari sumber aslinya (tidak melalui media perantara). Data primer diperoleh dengan metode angket (kuisioner). b) Data sekunder. Data sekunder adalah data yang diperoleh dalam bentuk yang sudah jadi, sudah dikumpulkan, dan diolah oleh pihak lain, biasanya dalam bentuk publikasi yang digunakan sebagai pendukung data primer. Data sekunder diperoleh dengan cara melihat transkrip nilai mata kuliah akuntansi responden tersebut dan data nilai di bagian akademik pada Jurusan atau Fakultas.

Selanjutnya data yang terkumpul akan dianalisis dengan menggunakan Analisis Regresi Berganda dan Uji Signifikansi (Uji F dan Uji T) yang sebelumnya akan diuji dahulu untuk Uji Kualitas data (validitas \& reliabilitas) serta Uji Asumsi Klasik yang terdiri dari Uji Multikolonearitas, Uji Autokorelasi, dan Uji Normalitas.

\section{HASIL DAN PEMBAHASAN}

1. Gambaran Umum Responden

Hasil kuesioner yang kembali dan dapat diolah ditunjukan pada tabel di 1. di bawah ini Tabel 1. Karakteristik Responden

\begin{tabular}{llll}
\hline \hline No & Keterangan & Jumlah & Persentase (\%) \\
\hline 1. & Jenis Kelamin & \\
\hline & Laki - laki & 44 & 77,19 \\
\hline Perempuan & 13 & 22,81 \\
\hline Jumlah kuesioner yang dapat diolah & 57 & 100 \\
\hline & & \\
\hline 2. & Usia & \\
\hline Berusia 20-23 tahun & 10 & 17,54 \\
\hline Berusia 24-26 tahun & 47 & 82,46 \\
\hline Jumlah kuesioner yang dapat diolah & 57 & 100 \\
\hline & 57 & 100 \\
\hline & & \\
\hline
\end{tabular}

Sumber : data primer yang diolah, 2016

Hasil dari karakteristik responden terlihat bahwa mayoritas responden berjenis kelamin laki-laki $(77,19 \%)$ dan berusia antara 24-26 tahun $(82,46 \%)$. 


\section{Hasil Uji Kualitas Data}

Dari hasil uji kualitas data diketahui bahwa data valid dan reliabel. Berikut hasil uji kualitas data dapat dilihat pada tabel 2. dan 3.

Tabel 2. Hasil Uji Validitas Kuesioner

\begin{tabular}{|c|l|c|c|c|}
\hline No & Variabel & Kisaran Korelasi & Signifikansi & Keterangan \\
\hline 1 & Kecerdasan emosional & $0.310^{* *}-0.671^{* *}$ & 0.01 & Valid \\
\hline 2 & Tingkat idealisme & $0.367^{* *}-0.725^{* *}$ & 0.01 & Valid \\
\hline 3 & Perilaku belajar & $0.267^{* *}-0.683^{* *}$ & 0.01 & Valid \\
\hline 4 & Locus of control & $0.330^{* *}-0.698^{* *}$ & 0.01 & Valid \\
\hline 5 & Pemahaman akuntansi & $0.322^{* *}-0.690^{* *}$ & 0.01 & Valid \\
\hline
\end{tabular}

Sumber: Data diolah, 2016

Tabel 3. Hasil Uji Reabilitas

\begin{tabular}{|c|l|c|c|}
\hline No & \multicolumn{1}{|c|}{ Variabel } & Nilai Cronbach Alpha & Keterangan \\
\hline 1 & Kecerdasan emosional & 0.949 & Reliabel \\
\hline 2 & Tingkat idealisme & 0.945 & Reliabel \\
\hline 3 & Perilaku belajar & 0.941 & Reliabel \\
\hline 4 & Locus of control & 0.939 & Reliabel \\
\hline 5 & Pemahaman akuntansi & 0,811 & Reliabel \\
\hline
\end{tabular}

Sumber: Data diolah, 2016

\section{Hasil Uji Asumsi Klasik}

Berdasarkan hasil pengujian pada dapat dilihat bahwa nilai VIF pada masing-masing variabel berjumlsh kurang dari 10 dan nilai tolerance kurang dari 1, sehingga dinyatakan semua variabel bebas dari gejala multikolinieritas.

Berdasarkan hasil uji Durbin-Watson dengan bantuan software SPSS for Windows yang telah dilakukan, diperoleh nilai Durbin-Watson sebesar 1,857 Nilai tersebut dibandingkan dengan nilai Durbin Watson tabel untuk $\mathrm{n}=57$ dengan $(\alpha) 0,05$ atau $5 \%$, maka nilai $\mathrm{d}_{\mathrm{U}}=$ 1,72 dan $\mathrm{d}_{\mathrm{L}}=1,41$. Jadi nilai uji Durbin Watson berada di antara $\mathrm{d}_{\mathrm{U}}$ dan $4-\mathrm{d}_{\mathrm{U}}$. Hal ini merupakan bukti tidak adanya autokorelasi positif maupun negatif. Adapun gambar kurva uji statistik d Durbin-Watson dapat dilihat pada Gambar 1. 


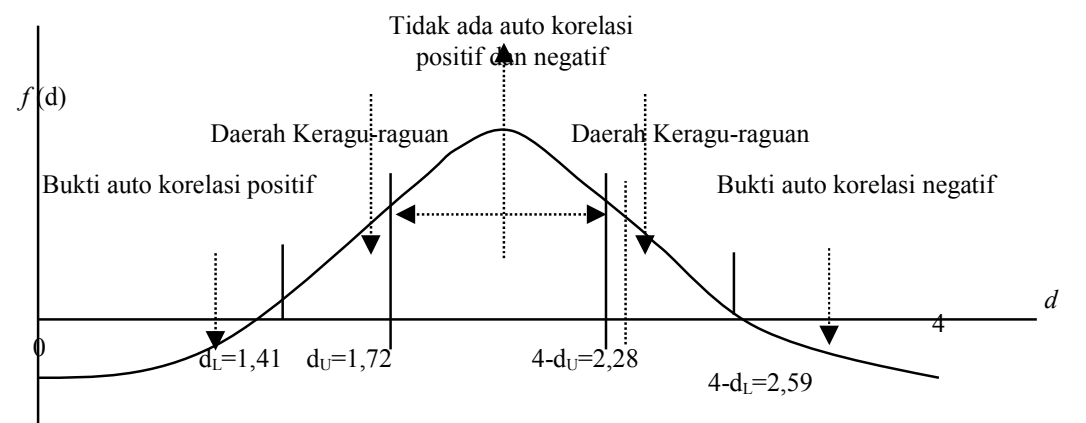

Gambar 3.1. Kurva Uji Statistik Durbin-Watson

Tabel 4. Hasil Uji Autokorelasi

Model Summary ${ }^{\mathrm{b}}$

\begin{tabular}{|l|r|r|r|r|r|}
\hline Model & $\mathrm{R}$ & R Square & $\begin{array}{c}\text { Adjusted R } \\
\text { Square }\end{array}$ & $\begin{array}{l}\text { Std. Error of } \\
\text { the Estimate }\end{array}$ & $\begin{array}{l}\text { Durbin- } \\
\text { Watson }\end{array}$ \\
\hline 1 & $.151^{\mathrm{a}}$ & .023 & .000 & 5.651 & 1.857 \\
\hline
\end{tabular}

a. Predictors: (Constant), total produk

b. Dependent Variable: totalpemahaman

Nilai Kolmogorov-Smirnov sebesar 0,752 dengan Asymp. Sig. (2-tailed) sebesar 0,624 lebih besar daripada alpha 0,05, sehingga nilai residual memenuhi asumsi klasik atau dinyatakan bahwa seluruh data berdistribusi normal.

\section{Analisa Regresi Berganda}

Berdasar hasil olah data dengan menggunakan SPSS didapat hasil persamaan dari Analisis Berganda adalah sebagai berikut:

$$
\mathrm{Y}=1,011+0,068 \mathrm{X}_{1}+0,052 \mathrm{X}_{2}+0,032 \mathrm{X}_{3}+0,030 \mathrm{X}_{4}+\varepsilon
$$

Dari persamaan tersebut dapat dijelaskan beberapa hal sebagai berikut: nilai konstanta sebesar 1,011 yang berarti bila kecerdasan emosional, tingkat idealisme, perilaku belajar dan locus of contrrol sama dengan nol, maka pemahaman akuntansi sebesar 1,011.

Koefisien $\mathrm{X}_{1}$ sebesar 0,068 berarti variabel kecerdasan emosional mempunyai hubungan yang positif dengan variabel pemahaman akuntansi, hal ini menunjukkan bahwa naiknya variabel kecerdasan emosional akan menaikkan variabel pemahaman akuntansi. Jika terjadi kenaikan variabel kecerdasan emosional sebesar satu persen maka akan menaikkan variabel pemahaman akuntansi sebesar 0,068 persen, dengan asumsi bahwa variabel lain tetap pada tingkat kepercayaan 95 persen.

Koefisien $\mathrm{X}_{2}$ sebesar 0,052 berarti variabel tingkat idealisme mempunyai hubungan yang positif dengan variabel pemahaman akuntansi, hal ini menunjukkan bahwa naiknya variabel tingkat idealisme akan menaikkan variabel pemahaman akuntansi. Jika terjadi kenaikan variabel tingkat idealis sebesar satu persen maka akan menaikan variabel pemahaman akuntansi sebesar 0,052 persen, dengan asumsi bahwa variabel lain tetap pada 
tingkat kepercayaan 95 persen.

Koefisien $\mathrm{X}_{3}$ sebesar 0,035 berarti variabel perilaku belajar mempunyai hubungan yang positif dengan variabel pemahaman akuntansi, hal ini menunjukkan bahwa naiknya variabel perilaku belajar akan menaikkan variabel pemahaman akuntansi. Jika terjadi kenaikan variabel perilaku belajar sebesar satu persen maka akan menaikkan variabel variabel pemahaman akuntansi sebesar 0,035 persen, dengan asumsi bahwa variabel lain tetap pada tingkat kepercayaan 95 persen.

Koefisien $\mathrm{X}_{4}$ sebesar 0,030 berarti variabel locus of control mempunyai hubungan yang positif dengan variabel pemahaman akuntansi, hal ini menunjukkan bahwa naiknya variabel locus of control akan menaikkan variabel pemahaman akuntansi. Jika terjadi kenaikan variabel locus of control sebesar satu persen maka akan menaikkan variabel variabel pemahaman akuntansi sebesar 0,035 persen, dengan asumsi bahwa variabel lain tetap pada tingkat kepercayaan 95 persen.

\section{Pengujian Hipotesis}

Untuk menguji pengaruh variabel independen secara bersama-sama terhadap variabel dependen digunakan uji F. Dari hasil perhitungan dengan tingkat keyakinan sebesar 95 persen atau $\alpha=0,05$ diperoleh nilai $F_{\text {tabel }}$ sebesar 2,719, sedangkan nilai $F_{\text {hitung }}$ sebesar 869,351 . Berikut tabel hasil output dengan uji F.

Tabel 6.Hasil uji F

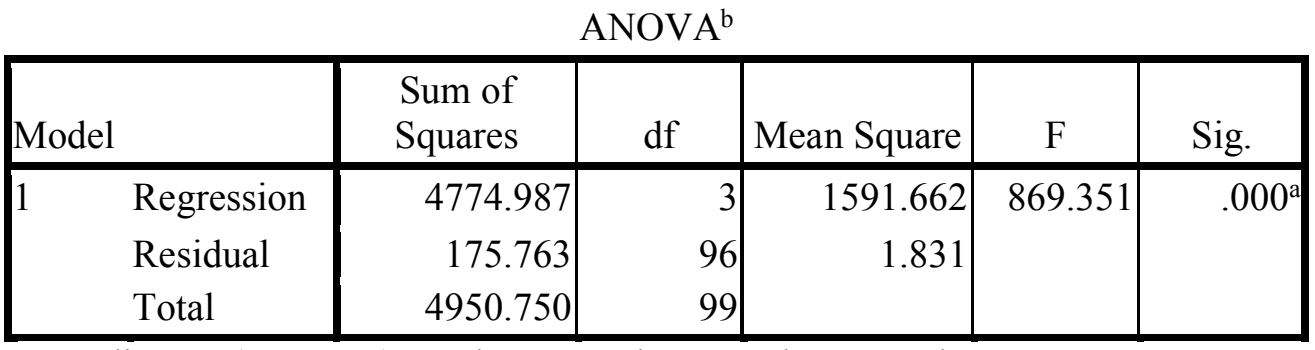

a. Predictors: (Constant), total_KE, total_TI, total_PB, total_LC

b. Dependent Variable: total_PA

Sumber: Data diolah,2016

Dalam kurva dapat dilihat pada gambar 2. sebagai berikut:

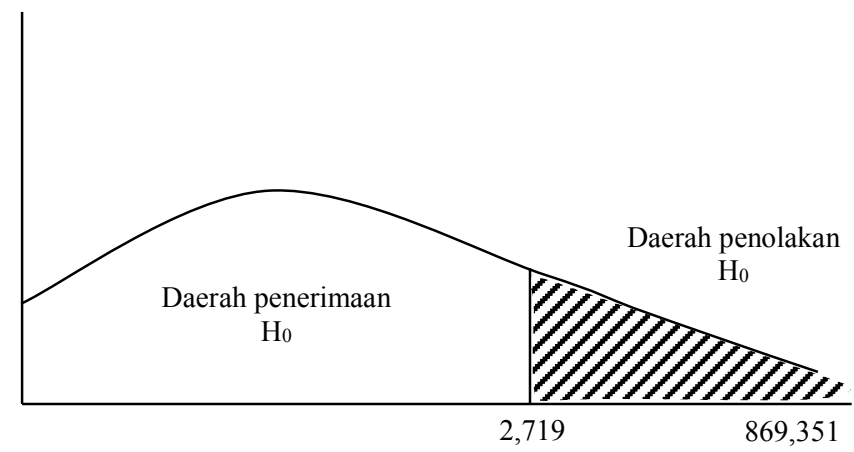

Gambar 2. Kurva uji F

Hal tersebut menunjukkan bahwa nilai $F_{\text {hitung }}>$ nilai $F_{\text {tabel }}$ atau berada pada daerah penolakan $\mathrm{H}_{0}$, sehingga dapat disimpulkan bahwa variabel kecerdasan emosional, tingkat 
idealisme, perilaku belajar dan locus of control secara bersama-sama mempunyai pengaruh yang signifikan terhadap pemahaman akuntansi.

Untuk mengetahui pengaruh secara parsial variabel kecerdasan emosional, tingkat idealisme, perilaku belajar dan locus of control terhadap pemahaman akuntansi digunakan uji t. Dari hasil analisis dengan menggunakan tingkat kesalahan $(\alpha)=0,05$ diketahui nilai $\mathrm{t}$ tabel sebesar 1,990. Berikut hasil output SPSS.

Tabel 6.Hasil uji t

Coefficients ${ }^{\mathrm{a}}$

\begin{tabular}{|c|c|c|c|c|c|c|}
\hline \multirow{2}{*}{\multicolumn{2}{|c|}{ Model }} & \multicolumn{2}{|c|}{$\begin{array}{l}\text { Unstandardized } \\
\text { Coefficients }\end{array}$} & \multirow{2}{*}{$\begin{array}{c}\text { Standardized } \\
\text { Coefficients }\end{array}$} & \multirow[b]{2}{*}{$\mathrm{t}$} & \multirow[b]{2}{*}{ Sig. } \\
\hline & & $\mathrm{B}$ & Std. Error & & & \\
\hline 1 & (Constant) & -.996 & 1.011 & & -.985 & .327 \\
\hline & total_KE & .169 & .068 & .059 & 2.496 & .014 \\
\hline & total_TI & .179 & .078 & .068 & 2.880 & .018 \\
\hline & total_PB & -.034 & .052 & -.013 & -.657 & .513 \\
\hline & total_LC & 1.405 & .035 & .947 & 40.254 & .000 \\
\hline
\end{tabular}

a. Dependent Variable: total_PA

Sumber: Data diolah, 2016

Berdasarkan tabel dapat dijelaskan pengaruh masing-masing variabel independen terhadap variabel dependen sebagai berikut: berdasarkan tabel diketahui nilai $t_{\text {hitung variabel }}$ kecerdasan emosional sebesar 2,469. Dengan menggunakan $\alpha=0,05$ diperoleh nilai $\mathrm{t}$ tabel sebesar 1,990. Dari hasil tersebut dapat dilihat bahwa nilai $\mathrm{t}$ hitung $>$ nilai $\mathrm{t}$ tabel. Hal ini menunjukkan bahwa variabel kecerdasan emosional berpengaruh positif signifikan terhadap variabel pemahaman akuntansi, sehingga hipotesis yang menyatakan bahwa kecerdasan emosional secara parsial berpengaruh signifikan terhadap kualitas laporan keuangan, diterima.

Berdasarkan tabel diketahui nilai $\mathrm{t}$ hitung variabel tingkat idealisme sebesar 2,880. Dengan menggunakan $\alpha=0,05$ diperoleh nilai $t$ tabel sebesar 1,990. Dari hasil tersebut dapat dilihat bahwa nilai $t_{\text {hitung }}>$ nilai $t_{\text {tabel. }}$. Hal ini menunjukkan bahwa variabel tingkat idealisme berpengaruh positif signifikan terhadap variabel pemahaman akuntansi, sehingga hipotesis yang menyatakan bahwa tingkat idealisme secara parsial berpengaruh signifikan terhadap kualitas laporan keuangan, diterima.

Berdasarkan tabel diketahui nilai $t$ hitung variabel perilaku belajar sebesar -0,657. Dengan menggunakan $\alpha=0,05$ diperoleh nilai $\mathrm{t}$ tabel sebesar 1,990. Dari hasil tersebut dapat dilihat bahwa nilai $t_{\text {hitung }}<$ nilai $t$ tabel- Hal ini menunjukkan bahwa variabel perilaku belajar tidak berpengaruh terhadap variabel pemahaman akuntansi, sehingga hipotesis yang menyatakan bahwa perilaku belajar secara parsial berpengaruh signifikan terhadap pemahaman akuntansi, ditolak.

Berdasarkan tabel diketahui nilai $\mathrm{t}$ hitung locus of control 40, 254. Dengan menggunakan $\alpha=0,05$ diperoleh nilai $\mathrm{t}$ tabel sebesar 1,990. Dari hasil tersebut dapat dilihat bahwa nilai $t$ hitung $>$ nilai $t$ tabel. Hal ini menunjukkan bahwa variabel locus of control berpengaruh positif terhadap pemahaman akuntansi, sehingga hipotesis yang menyatakan bahwa locus of control secara parsial berpengaruh signifikan terhadap kualitas pemahaman akuntansi, diterima. 


\section{Pembahasan}

Hipotesis yang menyatakan kecerdasan Emosional berpengaruh terhadap Pemahaman Akuntansi, diterima. Hasil penelitian ini konsisten dengan penelitian sebelumnya (Sugiartini 2008). Bahwa jika motivasi meningkat maka akan menyebabkan tingkat pemahaman akuntansi juga akan meningkat. Hasil ini sama dengan hasil distribusi jawaban responden yang menunjukan mahasiswa yang memiliki IPK tinggi cenderung mempunyai motivasi diri yang baik.

Hipotesis yang menyatakan tingkat Idealisme berpengaruh terhadap Pemahaman Akuntansi, diterima. Idealisme mengacu pada luasnya seseorang individu percaya bahwa keinginan konsekuensi dapat dihasilkan tanpa melanggar petunjuk moral (Forsyth, 1980). Tingkat idealisme yang melekat dalam diri mahasiswa akuntansi menunjukkan pengaruh signifikan terhadap kemampuan mereka terhadap pemahaman akuntansi. Mahasiswa akuntansi yang diorientasikan lebih idealis, akan lebih sensitif terhadap persoalan-persoalan terkait pemahaman akuntansi.

Hasil penelitian ini mendukung hasil penelitian yang dilakukan oleh penelitian Cheung (1999), Marwanto (2007) bahwa bahwa ada pengaruh pemikiran moral, tingkat idealisme, dan tingkat realitivisme mahasiswa akuntansi terhadap pertimbangan moral yang akan membantu peningkatan pemahaman terhadap sesuatu.

Hipotesis yang menyatakan perilaku belajar berpengaruh terhadap pemahaman akuntansi, ditolak. Hasil ini tidak mendukung penelitian yang dilakukan oleh Pratiwi (2010) . Mahasiswa yang mempunyai perilaku belajar kosisten dan cukup baik, serta mempunyai kebiasaan membaca buku tidak terbukti mampu meningkatkan pemahaman mereka atas pemahaman akuntansi, hal ini disebabkan fenomena mahasiswa akuntansi, khususnya di Kabupaten Banyumas cenderung bersikap idealis, mereka cenderung percaya bahwa keinginan konsekuensi dapat dihasilkan tanpa melanggar petunjuk moral, petunjuk moral di sini terkait dengan tata aturan perkuliahan.

Hal ini mendukung pendapat yang dikemukakan oleh Forsyth, (1980) bahwa mahasiswa akuntansi dalam menggunakan faktor-faktor pribadi mereka bervariasi dalam motivasi moral mereka yang mengarah pada pertimbangan dalam memprioritaskan nilai moral yang relatif berhubungan dengan nilai lainnya. Dalam proses ini dipengaruh oleh kemampuan dari faktor-faktor pribadi, antara lain pemikiran moral, tingkat idealsme, tingkat relativisme.

Hipotesis yang menyatakan locus of control berpengaruh terhadap kualitas pem ahaman akuntansi, diterima. Hasil penelitian ini tidak mendukung penelitian yang dilakukan Marwanto (2007). Locus of control telah dianggap suatu dari ciri watak kepribadian yang lebih teguh atau stabil yang ada pada diri seorang individu (Koford dan Pennu, 1992). Mahasiswa akuntansi yang dikarakterkan sebagai internal adalah lebih menunjukkan kemampuan untuk menemukan masalah-masalah moral dari mahasiswa-mahasiswa lain yang dikarakterkan sebagai ekternal (Rotter, 1990).

Hasil penelitian ini membuktikan bahwa adanya watak teguh dan stabil pada diri mahasiswa akan berpengaruh signifikan terhadap pemahaman intelektual mereka. Mereka yang selalu teguh untuk memahami sesuatu, yang selalu termotivasi ke arah yang lebih baik akan berdampak pada peningkatan pemahaman mereka terhadap kondisi, situasi dan proses pembelajaran. 


\section{KESIMPULAN DAN SARAN}

1. Kesimpulan

Penelitian ini menguji pengaruh kecerdasan emosional, tingkat idealisme, perilaku belajar dan locus of control mahasiswa terhadap pemahaman akuntansi. Hasil penelitian membuktikan bahwa: Kecerdasan Emosional berpengaruh terhadap Pemahaman Akuntansi,. Hasil penelitian ini konsisten dengan penelitian sebelumnya (Sugiartini 2008). Bahwa jika motivasi meningkat maka akan menyebabkan tingkat pemahaman akuntansi juga akan meningkat.

Tingkat Idealisme berpengaruh terhadap Pemahaman Akuntansi. Hasil penelitian ini mendukung hasil penelitian yang dilakukan oleh penelitian Cheung (1999), Marwanto (2007). Mahasiswa akuntansi yang diorientasikan lebih idealis, akan lebih sensitif terhadap persoalan-persoalan terkait pemahaman akuntansi.

Perilaku belajar tidak berpengaruh terhadap pemahaman akuntansi. Hasil ini tidak mendukung penelitian yang dilakukan oleh Pratiwi (2010). Mahasiswa yang mempunyai perilaku belajar kosisten dan cukup baik, serta mempunyai kebiasaan membaca buku tidak terbukti mampu meningkatkan pemahaman mereka atas pemahaman akuntansi, hal ini disebabkan fenomena mahasiswa akuntansi, khususnya di Kabupaten Banyumas cenderung bersikap idealis, mereka cenderung percaya bahwa keinginan konsekuensi dapat dihasilkan tanpa melanggar petunjuk moral, petunjuk moral di sini terkait dengan tata aturan perkuliahan.

Locus of control berpengaruh terhadap pemahaman akuntansi. Hasil penelitian ini tidak mendukung penelitian yang dilakukan Marwanto (2007). Hasil penelitian ini membuktikan bahwa adanya watak teguh dan stabil pada diri mahasiswa akan berpengaruh signifikan terhadap pemahaman intelektual mereka. Mereka yang selalu teguh untuk memahami sesuatu, yang selalu termotivasi ke arah yang lebih baik akan berdampak pada peningkatan pemahaman mereka terhadap kondisi, situasi dan proses pembelajaran.

\section{Keterbatasan}

Penelitian ini mempunyai beberapa keterbatasan atau kelemahan dalam beberapa hal, antara lain: Penelitian ini hanya menggunakan obyek penelitian mahasiswa akuntansi di Kabupaten Banyumas, sehingga mengurangi kemampuan dalam generalisasi hasil penelitian di luar objek tersebut. Selain itu juga skala likert yang digunakan untuk instrumen penelitian yang tidak seragam yang merupakan hasil dari replikasi kuesioner acuan jurnal utama Chan dan Leung (2006). Sehingga memiliki kemungkinan adanya perbedaan dalam rata-rata atau tingkat jawaban pernyataan yang diberikan oleh responden.

\section{Saran}

Berdasarkan keterbatasan diatas, maka saran yang bisa diberikan untuk penelitian di masa mendatang adalah:

1) Populasi yang digunakan tidak hanya mahasiswa mahasiswa akuntansi di Kabupaten Banyumas,, sehingga hasil penelitian dapat digeneralisasi untuk melihat sampel di luar Kabupaten Banyumas .

2) Skala likert yang digunakan untuk instrumen penelitian harus seragam untuk penelitian di masa yang akan datang. Sehingga memiliki bobot yang sama dalam rata-rata atau tingkat jawaban pernyataan yang diberikan oleh responden. 


\section{DAFTAR PUSTAKA}

Chan, Samuel Y.S. and Leung, Philomena (2006). The effect of accounting student's ethical reasoning and personel factors on their ethical sensitivity, Managerial Auditing Journal, Vol. 21, No. 4, pp. 436-457.

Cohen, J.R., Pant, L.W. and Sharp, D.J. (2001). An examination of differences in ethical decision-making between Canadian business students and accounting professionals, Journal of Business Ethics, Vol. 30 No. 4, pp. 319-36.

Cohen, J.R. and Bennie, N.M. (2006), The Applicability of a Contingent Factors Model to Accounting Ethics Research, Journal of Business Ethics, Vol. 68, pp. 1-18.

Forsyth, D.R. (1980). A taxonomy of ethical ideologies, Journal of Personality and Social Psychology, Vol. 39, pp. 175-84.

Fraedrich, J.P., \& Ferrell, O.C (1992a). Cognitive consistency of marketing managers in ethical situations, Journal of Academy of Marketing Science, 20, 245-252.

Ghozali, I. 2005. Aplikasi Analisis Multivariat dengan Program SPSS. Badan Penerbit Universitas Diponegoro. Semarang

Marwanto. 2007. Pengaruh pemikiran moral, tingkat idealisme, tingkat relativisme dan locus of control terhadap pertimbangan motivasi dan karakter mahasiwa akuntansi. Tesis, Universitas Diponegoro, Semarang. Tidak dipublikasikan

Pratiwi, Dina. 2010. Pengaruh kecerdasan emosional dan perilaku belajar terhadap tingkat pemahaman akuntansi mahasiswa pada perguruan tinggi di kota Mataram. Skirpsi, Univeristas Mataram. Mataram. Tidak dipulikasikan

Robbins, Stephen P. (2006). Organizational Behavior, Edisi Bahasa Indonesia, Indeks Gramedia, Jakartra.

Rotter, J.B. (1966). Generalized expectancies for internal versus external control of reinforcement, Psychological Monograph, General and Applied, Vol. 80 No. 1, (Whole No. 609).

Sugiartini. 2008. Pengaruh kecerdasan Emosional Terhadap Tingkat Pemahaman Akuntansi Pada Mahasiswa Strata Satu (S1) Jurusan Akuntansi

Sugiyono. 2004 dan 2005. Metode Penelitian Bisnis. Jakarta: Alpabeta

Sumarni, Murti dan Wahyuni Salamah. 2005. Metodologi Penelitian Bisnis. Penerbit ANDI: Yogyakarta 